\title{
Possible Metsulfuron Herbicide Detoxification by a Oryza sativa L. Glutathione S-transferase Enzyme.
}

\author{
Vinícius Costa Amador ${ }^{1}$ \\ https://orcid.org/0000-0002-7946-5665 \\ Edson Ferreira da Silva ${ }^{2}$ \\ https://orcid.org/0000-0001-9496-502X \\ Daniela Nadvorny ${ }^{3}$ \\ https://orcid.org/0000-0001-9154-764X

\section{Rafael Trindade Maia ${ }^{4}$} \\ https://orcid.org/0000-0002-5870-1091
}

${ }^{1}$ Federal Rural University of Pernambuco, Department of Agronomy, Recife, Pernambuco, Brazil; ${ }^{2}$ Federal Rural University of Pernambuco, Department of Agronomy, Recife, Pernambuco, Brazil; ${ }^{3}$ Federal Rural University of Pernambuco, Department of Pharmacy, Recife, Pernambuco, Brazil; ${ }^{4}$ Federal University of Campina Grande, Center of Semi-Arid Sustainable Development. Sumé, Paraíba, Brazil

Received: 2018.10.13; Accepted: 2019.11.25.

*Correspondence: vinicius.costa.amador@gmail.com, (V.C.A.).

\section{HIGHLIGHTS}

- Molecular docking to study molecular anchorage of a GST's rice and herbicides.

- Tau class GST's in plants may be able to detoxify herbicides.

- Tau-class GST in plants may be able to detoxify pesticides.

Abstract: Rice (Oryza sativa L.) is one of the most important crops in the world, and it is considered the primary source of nutritional layout in developing countries in Asia. The glutathione S-transferases (GSTs) superfamily confers to rice protection against biotic and abiotic stress, and herbicide resistance. However, the three-dimensional structure of a GST Tau class, is unsolved. The objectives of this work were to develop a reliable comparative model for the s-transferase glutathione class Tau 4 from rice, and simulate docking interactions, against herbicides bentazon and metsulfuron. Results showed that the predicted model is reliable and has structural quality. Ramachandran plot set $91.9 \%$ of the residues in the most favored regions. All complexes showed negative binding energies values; and metsulfuron docked to the glutathione tripeptide, and it represents a possible insilico evidence of glutathione conjugation with this herbicide.

Keywords: Molecular Modeling, OsGST, Herbicide, Docking, Bioinformatics, Computational Biology.

\section{INTRODUCTION}

Rice (Oryza sativa L.) is a crop of global significance, due its impact in agribusiness and nutritional value. It is the primary source of Asian developing countries nutritional diet. Despite this remarkable importance, there is a lack of studies to develop techniques that minimizes the potential problems inherent of this grain cultivation, such as competition with invasive plants [1]. 
In rice crop, the weed control has not been made for a long time due it is an open-area crop, free of invasive plants, in which situation no control measures are necessary. However, there is a lack of technologies and products aimed at the control of weeds in rice [2], in rotation with commercial crops such as soybean and corn. This problem, associated with the low capacity of competition against weeds, is one of the main obstacles of the rice introduction in agricultural systems in corrected soils [1].

Regarding the rice cultivation practices there are no consensus about technical features that are correlated with the competitive ability among weeds [3]. Systems that suffers with intrageneric and/or intraspecific competition explores the same niche that gives competitive advantage for the weed [4] is the actual problem found in the rice and red rice crop in Brazil [5]. Weed management can be done directly or indirectly. In the direct management, the activities are directed to the elimination of weeds by chemical, mechanical, manual and biological methods, while in the rice monoculture the chemical control the most important form of weed management, by the application of multiple herbicides in the cultivated area [1,6].

Due to the phytotoxicity of these compounds, the herbicides also damages the rice cultivation. The herbicide use can reach $85 \%$ of grain decrease [7]. An experiment about evaluative effects of the glyphosate, a broad-spectrum herbicide commonly used in rice monocultures, showed several counterproductive effects such as decreased height, number of juveniles, and grain losses up to $63 \%$ in $O$. sativa [8]. In addition to the damage caused by glyphosate, there are associated stress factors (biotic or abiotic), that induce free radicals production, such as oxidative reactions, resulting oxidative stress and irreversible cellular damage [8]. The gluthatione S-transferase enzyme superfamily confers to rice catalytic action, protection of biotic and abiotic stress, and herbicide resistance [10-11] by the conjugation reaction of the tripeptide glutathione (GSH) to a hydrophobic compound, and convert it in a more soluble and less toxic conjugated compound [12].

Glutathione S-transferases (GSTs) denotes a superfamily of catalytic proteins that are present in almost all living beings, being distributed in a great diversity of aerobic organisms, ranging from bacteria to human [10-11]. These enzymes are involved in several biological processes [13].

GSTs are usually found in the biological environment as homo or heterodimers (there may be the possibility of complexes), generally presenting two active sites by dimer that express activities independent of each other [14]. Each active site consists of: one for the tripeptide GSH (G-site) which is very specific for this tripeptide and is situated on $\mathrm{N}$-terminal domain, and another binding site which has a lower specificity for the electrophiles (H-site) on C-terminal domain [14].

GSTs have a large spectrum of specificity, which confers them effective metabolic properties several toxic components, characterizing them as the main proteins of phase II of the detoxification process [15].

Others studies demonstrated that the GST enzymes are associated with the tolerance of several crops to the harmful effects of herbicides, and grass resistance to these chemicals. The metabolic process of plant detoxification in some crops is activated by the enzyme as a direct response to the action of herbicides [16]. The aim of this study was to construct a theoretical model for a tau 4 Oryza sativa Indica glutathione Stransferase (OsJGSTU4) and perform docking simulations against bentazon-sodium and metsulfuron-methyl herbicides.

\section{MATERIAL AND METHODS}

\section{Homology modeling and model validation}

The OsJGSTU4 primary sequence was obtained from the NCBI database (https://www.ncbi.nlm.nih.gov/ - accession number: AAQ02686.1).

A local alignment was made against the PDB database (Protein Data Bank, http://www.rcsb.org/) through the local alignment algorithm "BLASTp" (Basic Local Aligment Tool for proteins, http://blast.ncbi) identity $(46,73 \%)$ and good resolution (1.25 ^) were obtained using a tau 4 family Populus trichocarpa glutathione Stransferase PtGSTU30 (PDB ID: 5j4u.1).

The template were saved in a PDB file, and the SWISS-MODEL server User Template tool (http://swissmodel.expasy.org/) was used to generate the model [17-18]. For the model validation, through Ramachandran plot analysis using the PROCHECK program [19] to verify the stereochemical quality of the structure.

Local quality was accessed by ANOLEA [20] and GROMOS force fields [21]. All the generated docked complexes were visualized with Visual Molecular Dynamics software (VMD v. 1.9.3) [22]. 


\section{Molecular Docking}

The structure of the herbicides used as ligands (Table 1.) were obtained from the ZINC database (http://zinc.docking.org/) in .mol2 files. These files were converted to .pdbqt in Autodock 4.2.623 (https://www.chpc.utah.edu/documentation/software/autodock.php), polar hydrogens were removed and their molecules were assigned with the Gasteiger parameters [24].

Table 1. Herbicides used in docking simulations

\begin{tabular}{|c|c|c|c|c|}
\hline Herbicide & $\begin{array}{l}\text { Molecular } \\
\text { Formula }\end{array}$ & $\begin{array}{c}\text { Metabolic } \\
\text { Rout }\end{array}$ & Structure & Access code \\
\hline $\begin{array}{l}\text { Bentazon } \\
\text { e-Sodium }\end{array}$ & $\begin{array}{c}\mathrm{C} 10 \mathrm{H} 12 \mathrm{~N} 2 \\
\text { O3S }\end{array}$ & $\begin{array}{l}\text { Benzothiadia } \\
\text { zinone }\end{array}$ & & $\begin{array}{c}\text { ZINC } \\
05442053\end{array}$ \\
\hline $\begin{array}{l}\text { Metsulfuro } \\
\text { n-Methyl }\end{array}$ & $\begin{array}{c}\text { C14H15N5 } \\
\text { O6S }\end{array}$ & Sulfonylurea & & $\begin{array}{c}\text { ZINC } \\
01532069\end{array}$ \\
\hline
\end{tabular}

The OsJGSTU4 theoretical model, was converted to .pdbqt file in Autodock, hydrogens and Kollman parameters were added [25]. The GSH was treated as a cofactor. Docking simulations were run on the Autodock 4.2.6 program (https://www.chpc.utah.edu/documentation/software/autodock.php) and the Lamarckian genetic algorithm (LGA) was chosen. The simulations had the following parameters: 10,000 replicates, energy analyzes per 1,500,000 and 27,000 generations, population size of 150 and mutation rates and crossing-over of 0.02 and 0.08 respectively. The 10 conformations were generated that were ranked based on the lowest energy and analyzed in the VMD [21] (http://www.ks.uiuc.edu/Research/vmd/).

\section{Eletrostatic Potential Map}

The molecular structure of the metsulfuron methyl molecule was obtained through the GAUSSVIEW 5.0 program. Then, this structure was submitted to quantum calculations of molecular geometry and harmonic frequency using the HF / 6-31G method in the GAUSSIAN 09 program package [27]. By the results of these calculations, the metsulfuron methyl electrostatic potential map was analyzed.

\section{RESULTS}

\section{Model Quality Evaluation and Validation}

The x-ray diffraction template PtGSTU30 (PDB ID: 5j4u.1) presented $2.25 \AA$ resolution [28], and acceptable identity value (46,73\%), revealing a homology between the Os/GSTU4 and PtGST30 proteins appropriate for the modeling what was perceived by the results with other Tau class used by Kilili [29]. The alignment presented a score of 210 bits and an e-value of $6 e-67$. The Figure 1 shows conserved regions 
between OsJGSTU4 (Oryza sativa L. Japonica glutathiona S-transferase tau 4) and AtGSTU (template) sequences, revealing important anchor residues like GLN 75 (black arrow on position 84) and LYS 111 (black arrow on position 120) conserved, while HIS 54 (black arrow on position 63) and LYS 56 (black arrow on position 65) are not conserved, as shown on Figure 1.

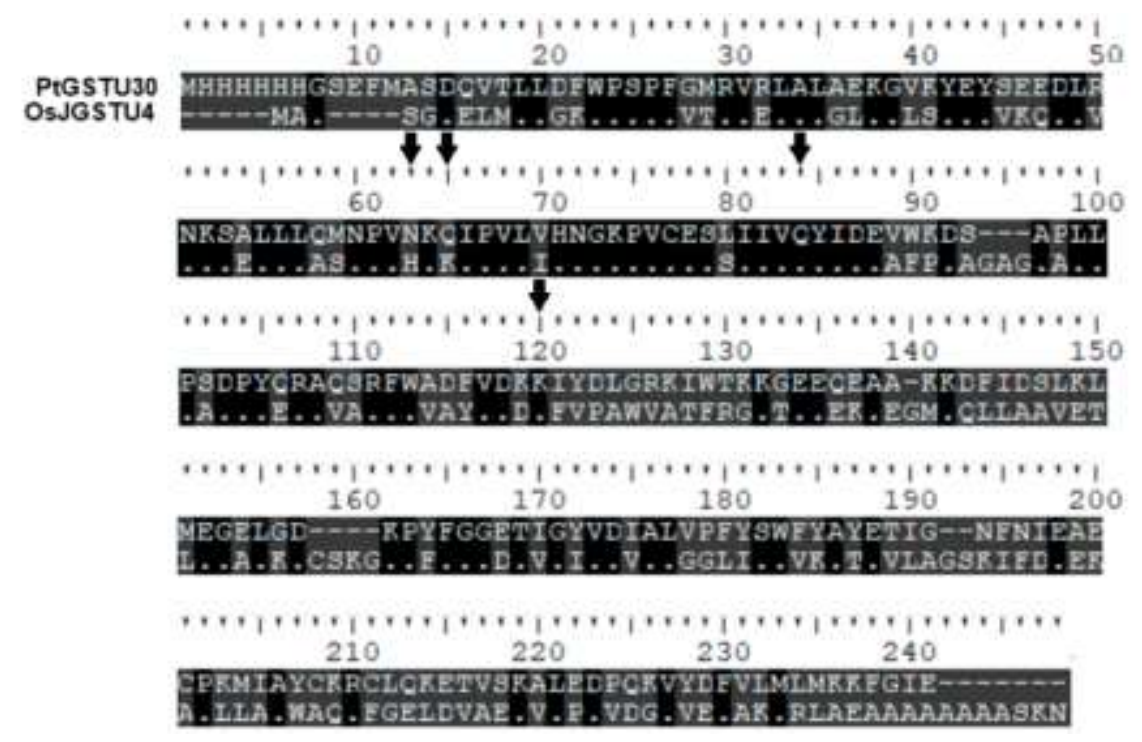

Figure 1. Alignment showing conserved sequences between OsJGSTU4 (Oryza sativa Japonica glutathiona Stransferase tau 4) and PtGSTU30 (template) sequences ("." Identify matchs).

According to Laskowski [19,30], a reliable predicted model are supposed to display over than $90 \%$ of residues situated in core regions of Ramachandran plot ( $A, B$ and $L)$, for Ho [31] some residues as glycine and proline has predictable and distinct distribution on the Ramachandran plot, as they present different stereochemical patterns. The stereochemical quality was accessed considering the Laskowski [28] critters, the Ramachandran graph showed $94.57 \%$ (418/442) of the residues in favorable regions, $100 \%(442 / 442)$ of all residues were in allowed regions as shown in Figure 2a., a model validation results by Maia and Nadvorny [32] had $93.9 \%$ of the residues in allowed regions and generated a satisfactory and validated model. Figure $2 \mathrm{~b}$. shows the local evaluation of the energy values along the polypeptide chain, and was shown predominantly in the negative region of the graph, revealing good stability of the theoretical model. The Zscore calculated by the server was -7.87 for the theoretical model, and approached it to models elucidated by NMR (Nuclear Magnetic Resonance) technique (Figure 2c.).
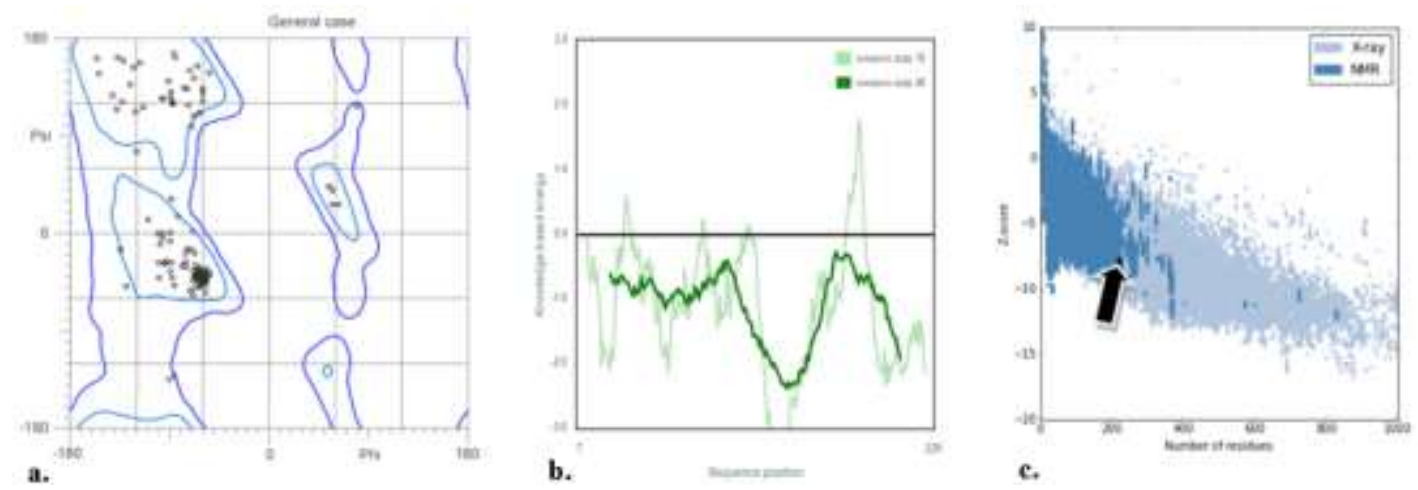

Figure 2. a. Ramachandran plot for OSJGSTU4 residues. b. Energy local model quality c. Z-score overall quality (black arrow).

According to Melo [20], van Gunsteren and Berendsen [33], ANOLEA and GROMOS the results were generally negative values, revealing a model with stable energy values, such as the results showed by Hamid [34]. 


\section{Molecular Docking}

The docking results for bentazon herbicide and the OsJGSTU4 ranked ten possible complexes based on intermolecular energy and binding energy scores (which were more stable than metsulfuron) the $\mathrm{H}$-bonds formed by the protein and the herbicide molecule, and their respective distances have been identified, as shown in the Table 2 [22].

Table 2 Docking energies for the ten best ranked OsJGSTU4-bentazon complexes (bentazon molecule is identified as "<0>").

\begin{tabular}{|c|c|c|c|c|}
\hline Complex & $\begin{array}{l}\text { Binding energy } \\
\text { (Kcal/mol) }\end{array}$ & $\begin{array}{l}\text { Intermolecular } \\
\text { energy (Kcal/mol) }\end{array}$ & $\begin{array}{c}\text { H-bonds (Reside atom - } \\
\text { Ligand atom) }\end{array}$ & Distance $\AA$ \\
\hline \multirow{3}{*}{1} & \multirow{3}{*}{-3.25} & \multirow{3}{*}{-3.55} & LYS $111: \mathrm{HZ1}-<0>0: \mathrm{O} 2$ & 1.68 \\
\hline & & & LYS $55: \mathrm{HZ3}-<0>0: \mathrm{HZ3}$ & 2.52 \\
\hline & & & VAL $53: 0-<0>0: 01$ & 3.0 \\
\hline \multirow{3}{*}{2} & \multirow{3}{*}{-3.23} & \multirow{3}{*}{-3.53} & LYS $111: \mathrm{HZ1}-<0>0: \mathrm{O} 2$ & 1.67 \\
\hline & & & LYS $55: H Z 3-<0>0: H Z 3$ & 2.53 \\
\hline & & & VAL $53: 0-<0>0: 01$ & 3.02 \\
\hline \multirow{3}{*}{3} & \multirow{3}{*}{-3.24} & \multirow{3}{*}{-3.53} & LYS $111: \mathrm{HZ1}-<0>0: \mathrm{O} 2$ & 1.65 \\
\hline & & & LYS $55: \mathrm{HZ3}-<0>0: \mathrm{HZ3}$ & 2.54 \\
\hline & & & VAL $53: O-<0>0: 01$ & 3.13 \\
\hline \multirow{3}{*}{4} & \multirow{3}{*}{-3.26} & \multirow{3}{*}{-3.55} & LYS $111: \mathrm{HZ1}-<0>0: \mathrm{O} 2$ & 1.67 \\
\hline & & & LYS $55: H Z 3-<0>0: H Z 3$ & 2.53 \\
\hline & & & VAL $53: 0-<0>0: 01$ & 3.07 \\
\hline \multirow{3}{*}{5} & \multirow{3}{*}{-3.24} & \multirow{3}{*}{-3.54} & LYS $111: \mathrm{HZ1}-<0>0: \mathrm{O} 2$ & 1.65 \\
\hline & & & LYS $55: \mathrm{HZ3}-<0>0: \mathrm{HZ3}$ & 2.54 \\
\hline & & & VAL $53: O-<0>0: 01$ & 3.07 \\
\hline \multirow{3}{*}{6} & \multirow{3}{*}{3.24} & \multirow{3}{*}{-3.53} & LYS $111: \mathrm{HZ1}-<0>0: \mathrm{O} 2$ & 1.66 \\
\hline & & & LYS $55: \mathrm{HZ3}-<0>0: \mathrm{HZ3}$ & 2.53 \\
\hline & & & VAL $53: 0-<0>0: 01$ & 2.96 \\
\hline \multirow{3}{*}{7} & \multirow{3}{*}{-3.24} & \multirow{3}{*}{-3.54} & LYS $111: \mathrm{HZ1}-<0>0: \mathrm{O} 2$ & 1.65 \\
\hline & & & LYS $55: \mathrm{HZ3}-<0>0: \mathrm{HZ3}$ & 2.54 \\
\hline & & & VAL $53: 0-<0>0: 01$ & 3.06 \\
\hline \multirow{3}{*}{8} & \multirow{3}{*}{-3.25} & \multirow{3}{*}{-3.55} & LYS $111: \mathrm{HZ1}-<0>0: \mathrm{O} 2$ & 1.67 \\
\hline & & & LYS $55: H Z 3-<0>0: H Z 3$ & 2.52 \\
\hline & & & VAL $53: 0-<0>0: 01$ & 3.08 \\
\hline \multirow{3}{*}{9} & \multirow{3}{*}{-3.24} & \multirow{3}{*}{-3.53} & LYS $111: \mathrm{HZ1}-<0>0: \mathrm{O} 2$ & 1.65 \\
\hline & & & LYS $55: H Z 3-<0>0: H Z 3$ & 2.55 \\
\hline & & & VAL $53: O-<0>0: 01$ & 3.19 \\
\hline \multirow{3}{*}{10} & \multirow{3}{*}{-3.25} & \multirow{3}{*}{-3.55} & LYS $111: \mathrm{HZ1}-<0>0: \mathrm{O} 2$ & 1.67 \\
\hline & & & LYS $55: \mathrm{HZ3}-<0>0: \mathrm{HZ3}$ & 2.52 \\
\hline & & & VAL $53: O-<0>0: 01$ & 3.08 \\
\hline
\end{tabular}

These results shows that herbicide-binding to catalytic site is possible to be performed by OsJGSTU4. All the complexes generated for OsJGSTU4-bentazon showed hydrogens bonds between betazon and the surrounding residues lysines 55, 111 and valine 53 formed $\mathrm{H}$-bonds among molecules what suggest that this are anchor resides (showed in Figure 3C) as shown in Figure 3. 

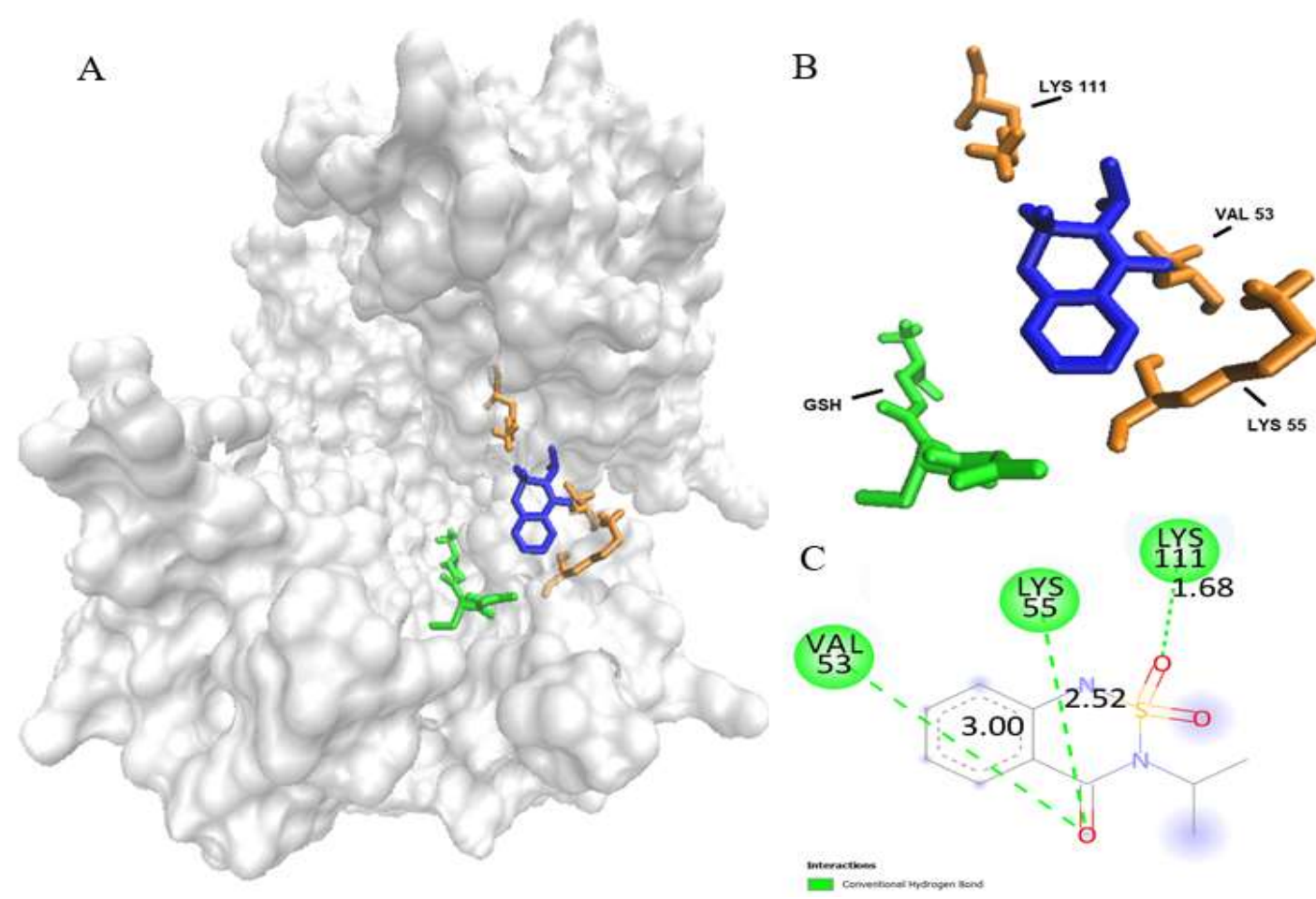

Figure 3. A Docked atoms and residues identification ( 4 A cutoff) around bentazon sodium herbicide $(<0>)$ visualization by Visual Molecular Dynamics, B Representation of the approximate residues of the binder, with respective binding distances, $C$ Identification of residues at a distance of 4 angstroms with Discovery Studio Visualizer.

The residues founded showed 10/10 results suggest that the residues are anchor resides for the metabolization process. A work done by Schröder and Collins[37] shows that herbicides like bentazon only can be conjugated among GST after cytP450 enzyme activation, Shimono et al. [38], corroborates that GST's and CYP where expressed during bentazon treatment. Is possible that OsJGSTU4 present a detoxifying potential for bentazon herbicide.

The, metsulfuron docking complexes showed 2/10 conformations that displays hydrogen bonds with the detoxifying subunit glutathione [12], indicating conjugation glutathione conjugation (Table 3). 
Table 3 Docking energies for the ten best ranked OsJGSTU4-metsulfuron complexes (metsulfuron molecule is identified as "<0>").

\begin{tabular}{|c|c|c|c|c|}
\hline Complex & $\begin{array}{l}\text { Binding Energy } \\
\text { (Kcal/mol) }\end{array}$ & $\begin{array}{c}\text { Intermolecular } \\
\text { Energy (Kcal/mol) }\end{array}$ & $\begin{array}{c}\text { H-bonds (Reside atom - } \\
\text { Ligand atom) }\end{array}$ & $\begin{array}{c}\text { Distance } \\
\AA\end{array}$ \\
\hline 1 & -2.34 & -4.13 & $\begin{array}{l}\text { GLN 134: O }-<0>0: \mathrm{N3} \\
\text { LYS 111: HZ1 - <0> 0:O5 } \\
\text { LYS 111: HZ2 - <0>0:N1 } \\
\text { LYS 56: HZ1 }-<0>0: O 6\end{array}$ & $\begin{array}{l}3.15 \\
1.72 \\
1.79 \\
1.95\end{array}$ \\
\hline 2 & -2.31 & -4.1 & $\begin{array}{l}\text { LYS 111: HZ1-<0>0:O2 } \\
\text { LYS 111: HZ3 -<0>0:O6 } \\
\text { LYS 56: HZ1 }-<0>0: O 3\end{array}$ & $\begin{array}{l}1.76 \\
2.07 \\
1.85\end{array}$ \\
\hline 3 & -2.67 & -4.46 & $\begin{array}{c}\text { ARG } 121: \mathrm{HH} 22-<0>0: \mathrm{O} 3 \\
\text { ARG } 121: \mathrm{HH} 12-<0>0: \mathrm{O} 2 \\
\text { LYS 55:HZ2 - <0>0:O6 } \\
\text { LYS } 56 \mathrm{HZ1}-<0>0: \mathrm{O} 3\end{array}$ & $\begin{array}{l}2.02 \\
2.03 \\
2.14 \\
2.37\end{array}$ \\
\hline 4 & -2.39 & -4.18 & $\begin{array}{l}\text { ARG } 225 \mathrm{HH} 11-<0>0: \mathrm{N} 2 \\
\text { ARG } 121: \mathrm{HH} 22-<0>0: \mathrm{O} \\
\text { ARG 121:HH12-<0>0:O5 }\end{array}$ & $\begin{array}{l}1.99 \\
1.87 \\
2.44 \\
\end{array}$ \\
\hline 5 & -2.4 & -4.19 & $\begin{array}{l}\text { GSH 1:H12-<0>0:N3 } \\
\text { LYS 56:HZ1 - <0>0:O2 } \\
\text { LYS 111: HZ1 - <0>0:N5 } \\
\text { HIS 54: HD1 - <0>0:O5 }\end{array}$ & $\begin{array}{l}2.05 \\
2.05 \\
3.04 \\
2.72 \\
\end{array}$ \\
\hline 6 & -2.41 & -4.2 & LYS 55:HZ2 - <0>0:O2 & 1.81 \\
\hline 7 & -2.38 & -4.17 & $\begin{array}{c}\text { LYS 111: HZ1-<0>0:O3 } \\
\text { LYS 111: HZ3 -<0>0:O5 } \\
\text { LYS 56:HZ1 }-<0>0: O 2\end{array}$ & $\begin{array}{l}2.01 \\
1.72 \\
1.70\end{array}$ \\
\hline 8 & -3.18 & -4.97 & $\begin{array}{c}\text { LYS 56: HZ1 - <0>0:O2 } \\
\text { LYS 111: HZ1 - <0>0:O3 } \\
\text { GSH 1:H12-<0>0:N3 }\end{array}$ & $\begin{array}{l}1.56 \\
1.88 \\
2.13\end{array}$ \\
\hline 9 & -2.65 & -4.44 & ARG 121:HH22 - <0>0:O3 & 1.74 \\
\hline 10 & -2.56 & -4.35 & $\begin{array}{l}\text { ASP } 110: \mathrm{O}-<0>0: \mathrm{N3} \\
\text { LYS 111:HZ1 - <0>0:O2 } \\
\text { LYS 56:HZ1 - <0>0:O4 } \\
\text { LYS 56:HZ2 - <0>0:O5 }\end{array}$ & $\begin{array}{l}2.91 \\
1.63 \\
1.77 \\
2.33\end{array}$ \\
\hline
\end{tabular}

The anchors residues seems to be two lysines at 56 and 111 positions, and arginines at 121 and 225 positions interact through hydrogen bonding, all residues located on the catalytic G-site of the enzyme (Figure 3) and a GSH through covalent bound listed in Table 3.

It is probably that OsJGSTU4 metabolizes metsulfuron herbicide through GSH-conjugation[12] and the best distance result (eighth place) is showed in Figure 4. 

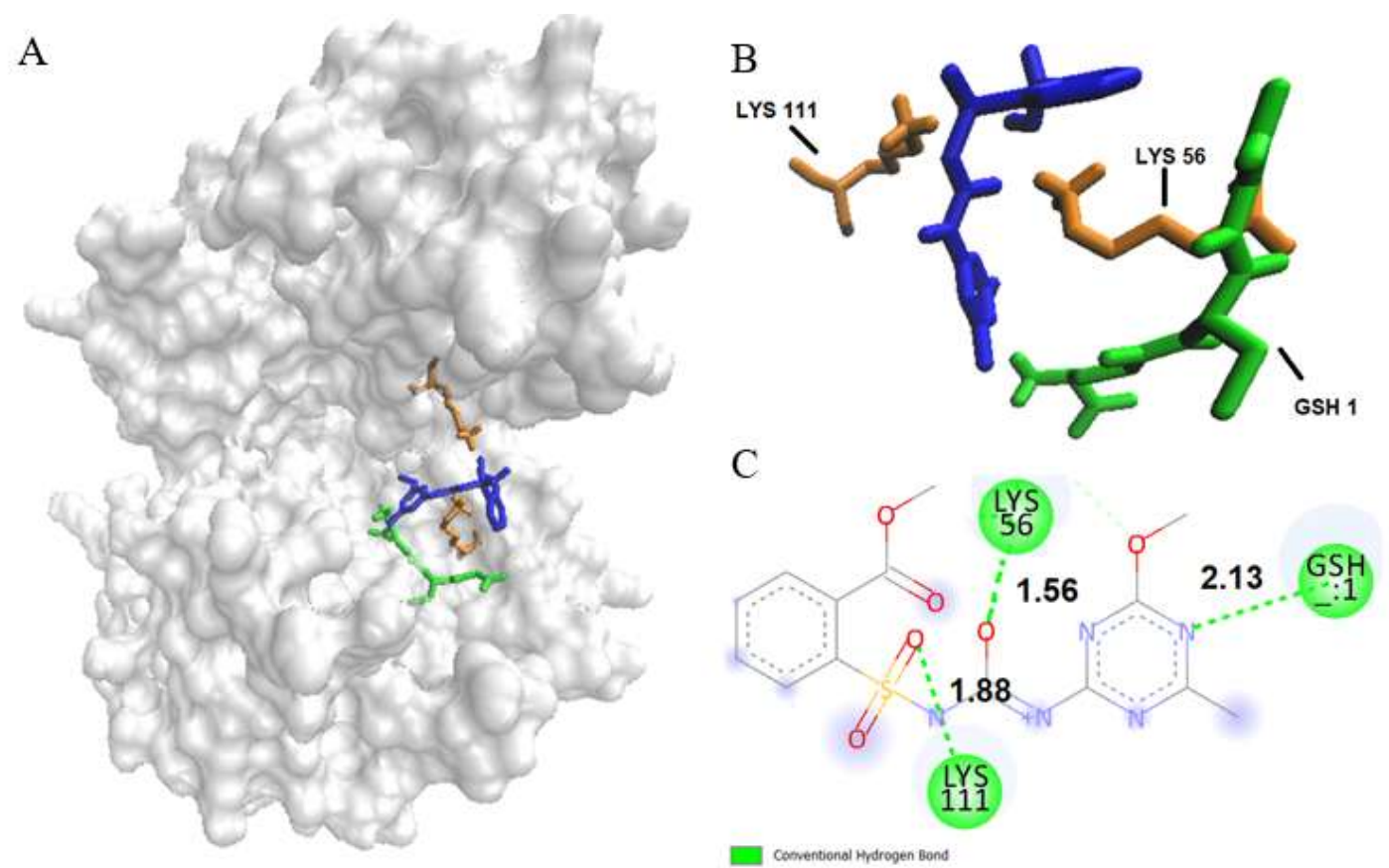

Figure 4. A Docked atoms and residues identification (4 $\AA$ cutoff) around metsulfuron-methyl herbicide $(<0>)$ visualization by Visual Molecular Dynamics, B Representation of the approximate residues of the binder, with respective binding distances, $C$ Identification of important residues at a distance of 4 angstroms (with respective bonding distances) visualization by Discovery Studio Visualizer

A work done by Lajmanovich and Junges [39] showed a correlation between metsulfuron methyl and the superfamily of GST expression, another work using Triticum aestivum organism done by Lu et al. [40] corroborates with the results above mentioned, its possible that OsGSTU4 is one of the superfamily members that suffer the same expression effect indicating the correlation between the herbicide metsulfuron and OSJGSTU4.

Although all residues displayed in docking tables for bentazon and metsulfuron results are located near to the G binding site, according to GHECOM (http://strcomp.protein.osaka-u.ac.jp/ghecom/cgibin/submit_ghecom.cgi) server prediction $[35,36]$ as shown by Figure 5.

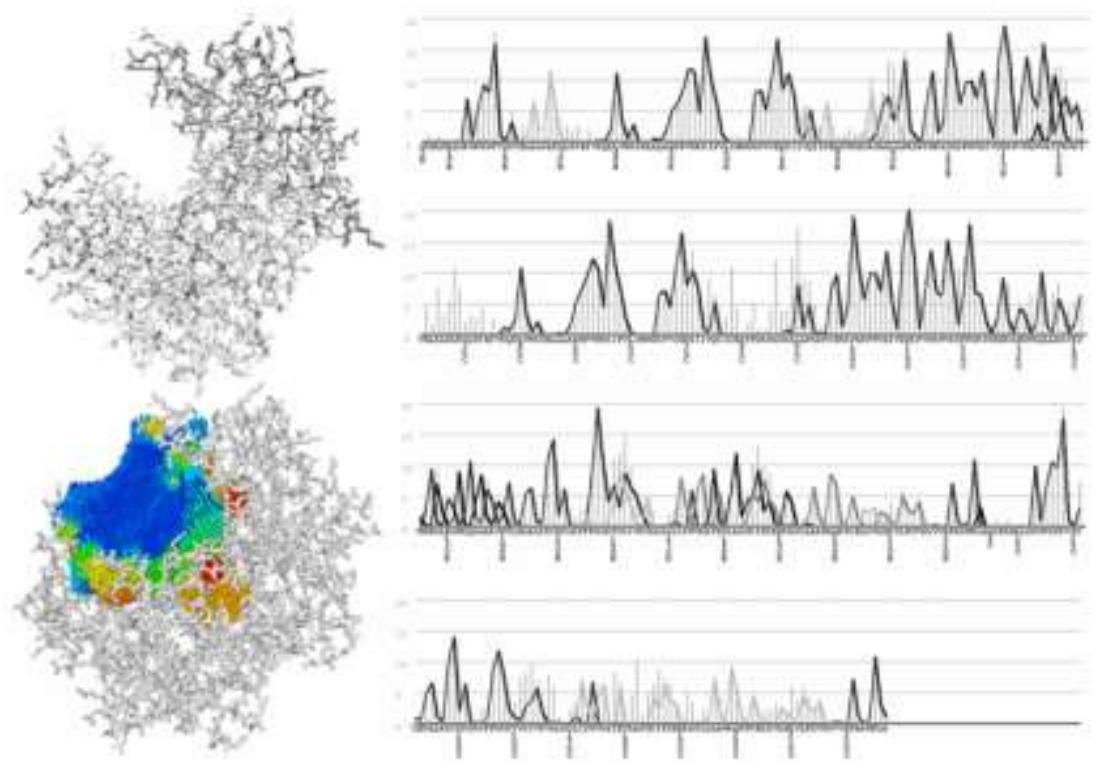

Figure 5. Best theoretical protein (OsGSTU4) pockets representation (dark spheres region) and the representation of the best result pocket along the polypeptide chain (must high and dark curves) using mathematical morphology. 


\section{Eletrostatic potential map}

Quantum calculations are able to provide detailed information of a particular molecule. This is due to electronic parameters are one of the main factors that rules the interaction between the components of a molecular system. In this context, the molecular electrostatic potential map (MEP) appears as an alternative in order to understand the electrostatic contribution of the environment. The interaction of metsulfuron methyl with the protein can occur by different means, such as hydrogen bonds or electrostatic interactions. One way to assess this issue is by mapping the electrostatic potential. This type of analysis is able to demonstrate the most positive (red), negative (blue) and neutral (green) molecular regions. In this way, we can verify the molecular sites with greater probability of interaction with the more positive or negative regions of the external environment, including the protein.

The Figure 6 clearly shows the presence of electrostatic interactions. Regions of high negative density are observed around sulfur-bound oxygen, while positive sites are more strongly present in the nuclei located at the molecular center.

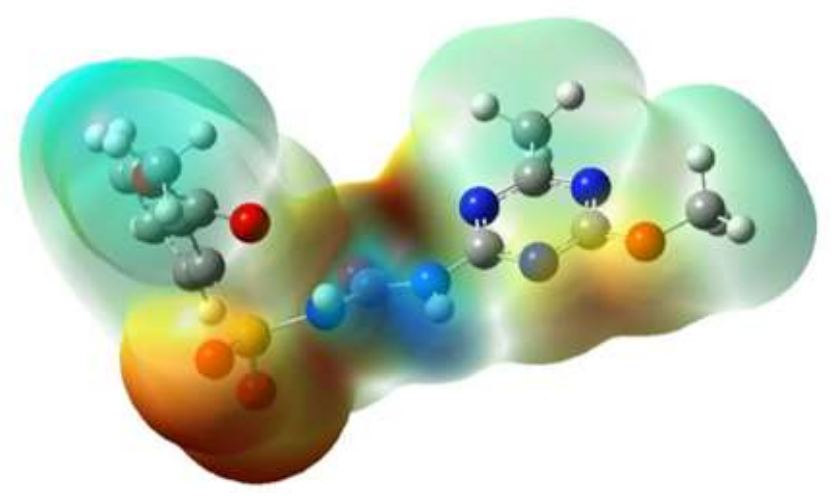

Figure 6. Electrostatic potential of metsulfuron methyl herbicide.

This charge distribution expresses the high probability of molecular interactions occurring between the herbicide and the protein. The negative charges of the chemical structure induces interactions with the negative charged amino acids Lys, Arg and His, from the catalytic site. Thus, in addition to the presence of hydrogen bonds previously discussed, we can suggest that electrostatic interactions also contribute to the complexation of metsulfuron methyl and system stability.

\section{CONCLUSION}

Here we present a in silico evidence that the inhibition enzyme OsJGSTU4 could display an important role in herbicide tolerance/resistance. Once rice is one of the most important crops around the world, bentazon and metsulfuron is largely used in its culture, the OsJGSTU4 can be used directed to metabolize and confers resistance/tolerance to this herbicides. This lead us to conclude that is highly probable that OsJGSTU4 aims to inhibit and/or metabolize bentazon and metsulfuron and confers to rice a herbicide resistance/tolerance to this compound. The residues situated on positions $43,53,54,55,56,111,121$ and 225 are important anchor residues, the majority of interactions with lysines near the $\mathrm{G}$ site suggest that lysins play an important role during the anchoring of these xenobiotics. The results presented on this research can be extremely useful for bioengineering by the structural and functional information. The OsJGSTU4 can be a biotechnological target for improve herbicide resistance in Oryza sativa L.

Funding: Coordenação de Aperfeiçoamento de Pessoal de Nível Superior - Brasil (CAPES), grant number 001".

Acknowledgments: We thank to BIOMAT group for computational resources gently granted

Conflicts of Interest: "The authors declare no conflict of interest." 


\section{REFERENCES}

1. Burlando B, Cornara L. Therapeutic properties of rice constituents and derivatives (L.): A review update. Trends Food Sci Technol. 2014; 40(1):82-98.

2. Radosevich SR, Holt J, Ghersa C. Weed ecology: Implications for Management. Wiley: New York; 1997.

3. Ni H, Moody K, Robles RP, Paller EC, Lales JS. Oryza sativa plant traits conferring competitive ability against weeds. Weed Sci. 2000; 48(2):200-204.

4. Fleck NG, Agostinetto D, Galon L, Schaedler CE. Competitividade relativa entre cultivares de arroz irrigado e biótipo de arroz-vermelho. Planta daninha. 2008;26(1):101-111.

5. Agostinetto D, Fleck NG, Rizzardi MA, Vidal RA, Costa ELN. Influência de cultivares de arroz e épocas da adubação nitrogenada nas relações de interferência da cultura com cultivar simulador de infestação de arrozvermelho. Planta daninha. 2004; 22:185-193.

6. Eberlein CV, Guttieri MJ, Mallory-Smith CA, Thill DC, Baerg RJ. Altered acetolactate synthase activity in ALSinhibitor resistant prickly lettuce (Lactuca serriola). Weed Sci. 1997;45(2):212-217.

7. Fleck NG, Noldin J, Menezes V, Pinto J, Eberhardt DS. Manejo e controle de plantas daninhas em arroz irrigado. In: Vargas L, Roman ES, editor. Manual de manejo e controle de plantas daninhas. Embrapa Uva e Vinho. Bento Gonçalves: Rio Grande do Sul; 2004. p. 251-321.

8. Ferreira FB, Pinto JJO, Roman ES, Galon L, Rezende AL, Procópio SO. Consequências da deriva simulada do herbicida Glyphosate sobre a cultura do arroz irrigado (Oryza sativa L.). R. Bras. Agrociência. 2006; 12(3): 309312.

9. Blokhina O, Virolainen E, Fagerstedt KV. Antioxidants, oxidative damage and oxygen deprivation stress: a review. AoB Plants. 2003; 91(2): 179-194.

10. Frova C. Glutathione transferases in the genomics era: new insights and perspectives. Biomol. Eng 2006; 23(4):149-169.

11. Frova C. The plant glutathione gene family: genomic structure, functions, expression and evolution. Physiol Plant.. 2003; 119(4): 469-479.

12. Yamamoto K, Usuda K, Kakuta Y, Kimura M, Higashiura A, Nakagawa A, Aso Y, Suzuki M. Structural basis for catalytic activity of a silkworm Delta-class glutathione transferase. Biochim. Biophys. Acta (BBA)-General Subjects. 2012; 1820(10): 1469-1474.

13. Freitas DRJ, Junior ISV, Masuda A. Expressão e Atividade Enzimática de Glutationa S-Transferase em Tecidos de Fêmeas de Boophilus microplus. Rev. Bras. Parasitol. Vet. 2008; 17(2):99-104.

14. Danielson UH, Mannervik B. Kinetic independence of the subunitsof cytosolic glutathione transferase from the rat. Biochem. J. 1985; 231(2): 263-267.

15. Enayati AA, Ranson H, Hemingway J. Insect glutathione transferases and insecticide resistance. Insect Mol Biol. 2005; 14(1):3-8.

16. Edwards R, Brazier-Hicks M, Dixon DP, Cummins I. Chemical manipulation of antioxidante defenses in plants. Adv. Bot. Res. 2005, 42: 1-32.

17. Arnold K, Bordoli L, Kopp J, Schwede T. The SWISS- MODEL Workspace: A web-based environment for protein structure homology modelling. Bioinformatics. 2006; 22: 195-201.

18. Kiefer F, Arnold K, Künzli M, Bordoli L, Schwede T. The SWISS- MODEL Repository and associated resources. Nucleic Acids Res. 2009; 37: 387-392.

19. Laskowski RA, MacArthur MW, Moss DS, Thornton JM. PROCHECK - a program to check the stereochemical quality of protein structures. J. Appl. Crystallogr. 1993; 26(2): 283- 291.

20. Melo F, Feytmans E. Assessing protein structures with a non-local atomic interaction energy. J. Mol. Biol. 1998; 277(5): 1141-1152.

21. Van Gunsteren WF, Daura X, Mark AE. GROMOS force field. In: Schleyer PVR, Schreiner PR, Schaefer III HF, Jorgensen WL, Thiel W, Glen RC, Allinger LN, Clark T, Gasteiger, editor. Encyclopedia of computational chemistry. 1998 p. 1211-1216.

22. Surhone LM, Timpledon MT, Marseken SF. Visual Molecular Dynamics [J]. Version 1.9.3 [software] 2010. Betascript Publishing. 2010. Available: https://www.ks.uiuc.edu/Research/vmd/.

23. Morris GM, Huey R, Lindstrom W, Sanner MF, Belew RK, Goodsell DS, Olson AJ. Autodock4 and AutoDockTools4: automated docking with selective receptor flexibility. J. Comput. Chem. 2009, 16: 2785-2791.

24. Gasteiger J, Marsili M. Iterative partial equalization of orbital electronegativity - a rapid access to atomic charges. Tetrahedron. 1980; 36(22): 3219-3228. 
25. Weiner SJ, Kollman PA, Case DA, Singh UC, Ghio C, Alagona G, Profeta S, Weiner P. A new force field for molecular mechanical simulation of nucleic acids and proteins. J. Am. Chem. Soc. 1984; 106: 765-784.

26. Dassault Systèmes BIOVIA, Discovery Studio Modeling Environment, Release 2017, San Diego: Dassault Systèmes, 2016.

27. Frisch J, Trucks GW, Schlegel HB, Scuseria GE, Robb MA, Cheeseman JR, Montgomery JA Jr, Vreven T, Kudin KN, Burant JC, et al. Gaussian 03, Revision A.1; Gaussian, Inc.: Pittsburgh, PA, USA, 2003

28. Thom R, Cummins I, Dixon D, Edwards D, Cole D, Lapthorn A. Structure of a Tau Class Glutathione S-Transferase from Wheat Active in Herbicide Detoxification. J. Biochem. 2002; 41(22): 7008-7020.

29. Kilili KG, Atanassova N, Vardanyan A, Clatot N, Al-Sabarna K, Kanellopoulos PN, Makris AM, Kampranis SC. Differential roles of tau-class glutathione S-transferases in oxidative stress. J. Biol. Chem. 2004; 279(23): 2454024551.

30. Laskowski RA, MacArthur MW, Thornton JM. PROCHECK: validation of protein-structure coordinates. International Tables for Crystallography F. 2012; 21(4): 684-687.

31. Ho BK, Brasseur R. The Ramachandran plots of glycine and pre-proline. BMC structural biology. 2005; 5(1): p. 14.

32. Maia RT, Nadvorny D. Molecular docking of Anopheles gambiae and Aedes aegypti glutathione S-transferases epsilon 2 (GSTE2) against usnic acid: an evidence of glutathione conjugation. Braz. Arch. Biol. Technol. 2014;57(5): 689-694.

33. van Gunsteren WF, Berendsen HJ. Computer simulation of molecular dynamics: Methodology, applications, and perspectives in chemistry. Angew. Chem. Int. Ed. Engl. 1990; 29(9): 992-1023.

34. Hamid AAA, Wong EL, Joyce-Tan KH, Shamsir MS, Hamid THAT, Huyop F. Molecular modelling and functional studies of the non-stereospecific $\alpha$-haloalkanoic acid Dehalogenase (DehE) from Rhizobium sp. RC1 and its association with 3-chloropropionic acid ( $\beta$-chlorinated aliphatic acid). Biotechnol. Biotechnol. Equip. 2013; 27(2): 3725-3736.

35. Kawabata T. Detection of multi-scale pockets on protein surfaces using mathematical morphology. Proteins. 2010; 78: 1195-1121.

36. Kawabata $T$, Go N. Detection of pockets on protein surfaces using small and large probe spheres to find putative ligand binding sites. Proteins. 2007; 68: 516-529.

37. Shimono M, Sugano S, Nakayama A, Jiang CJ, Ono K, Toki S, et al. Rice WRKY45 plays a crucial role in benzothiadiazole-inducible blast resistance. Plant Cell. 2007; 19: 2064-2076.

38. Schröder P, Collins C. Conjugating Enzymes Involved in Xenobiotic Metabolism of Organic Xenobiotics in Plants. International Journal of Phytoremediation. 2007; 4(4): 247-265.

39. Lajmanovich RC, Junges CM, Attademo AM, Peltzer PM, Cabagna-Zenklusen MC, Basso A. Individual and Mixture Toxicity of Commercial Formulations Containing Glyphosate, Metsulfuron-Methyl, Bispyribac-Sodium, and Picloram on Rhinella arenarum Tadpoles. Water Air Soil Pollut. 2013; 224: 1404

40. Lu YL, Liang L, Yang $\mathrm{H}$. Joint ecotoxicology of cadmium and metsulfuron-methyl in wheat (Triticum aestivum). Environ Monit Assess. 2013; 185(4): 2939-2950.

2020 by the authors. Submitted for possible open access publication under the terms and conditions of the Creative Commons Attribution (CC BY NC) license (https://creativecommons.org/licenses/by-nc/4.0/). 